\title{
PENGARUH KUALITAS PENDIDIKAN TERHADAP KEPUASAN LULUSAN DI SEKOLAH TINGGI ILMU KESEHATAN RESPATI TASIKMALAYA
}

Oleh :

Annisa Rahmidini, Firman F. Wirakusumah, Sari Puspa Dewi

\section{A. Abstrak}

Tingginya tingkat persaingan antara institusi pendidikan mengakibatkan setiap institusi harus dapat mengelola institusinya secara professional. Institusi pendidikan dapat mengatasi daya saing yang tinggi dengan memiliki mutu/kualitas pendidikan yang baik. Keputusan perguruan tinggi melakukan tindakan perbaikan kualitas pendidikan yang sistematis merupakan payung yang menentukan dalam menindaklanjuti keluhan mahasiswa dari suatu kegagalan sehingga pada akhirnya mampu meningkatkan kepuasan lulusan. Tujuan penelitian ini adalah menganalisis pengaruh kualitas pendidikan (tatakelola, pengabdian pada masyarakat, kurikulum program studi, proses pembelajaran, sumber daya manusia, suasana akademik, penelitian dan publikasi, kemahasiswaan, keuangan, serta prasarana dan sarana) terhadap kepuasan lulusan di Sekolah Tinggi Ilmu Kesehatan (STIKes) Respati Tasikmalaya.

Jenis penelitian kuantitatif dan metode yang digunakan adalah metode survey analitik dengan desain penelitian yaitu cross sectional. Populasi dalam penelitian ini adalah seluruh lulusan STIKes Respati Tasikmalaya dua tahun terakhir yaitu Angkatan VII dan VIII berjumlah 201 lulusan. teknik pengambilan sampel pada penelitian ini menggunakan simple random sampling sebanyak 106 lulusan diambil. Metode pengumpulan data dalam penelitian ini adalah dengan kuesioner.

Hasil analisis data menunjukkan bahwa terdapat pengaruh positif antara kualitas pendidikan terhadap kepuasan lulusan di Sekolah Tinggi Ilmu Kesehatan Respati Tasikmalaya. Diharapkan STIKES Respati Tasikmalaya meningkatkan kualitas pendidikan agar lulusan dapat merasa puas.

Kata kunci : Kualitas pendidikan, kepuasan lulusan, perguruan tinggi. 


\section{B. Latar Belakang}

Saat ini terdapat kurang lebih 661 institusi pendidikan kebidanan yang telah berdiri di Indonesia. Tingginya tingkat persaingan antara institusi pendidikan mengakibatkan setiap institusi harus dapat mengelola institusinya secara profesional. Institusi pendidikan dapat mengatasi daya saing yang tinggi dengan memiliki mutu/kualitas pendidikan yang baik. Persoalan mutu pada pendidikan tinggi menjadi penting untuk dijadikan satu kajian khusus dalam upaya perbaikan pendidikan yang akan berdampak pada pembangunan Indonesia di berbagai bidang, karena di pendidikan tinggi inilah para pembuat kebijakan, ilmuan, seniman, dan para perekayasa teknologi seharusnya lahir dengan tidak hanya mementingkan kepintaran, tetapi lebih dari itu pembangunan karakter generasi penerus bangsa ke depan (Hamidin, 2011).

Peningkatan kemampuan untuk mengelola dan mengembangkan perguruan tinggi sudah sangat dirasakan perlu, termasuk untuk menggunakan prinsip-prinsip manajemen modern berorientasi pada mutu/kualitas. Bagi para pengelola perguruan tinggi, sistem manajemen mutu pada hakekatnya berinti pada perbaikan terus menerus untuk memperkuat dan mengembangkan mutu lulusan sehingga dapat diserap oleh kalangan instansi dan pasar tenaga kerja (Aprilia, 20110). Keputusan perguruan tinggi melakukan tindakan perbaikan kualitas pendidikan yang sistematis merupakan payung yang menentukan dalam menindaklanjuti keluhan mahasiswa dari suatu kegagalan sehingga pada akhirnya mampu meningkatkan kepuasan lulusan (Elu, 2005).

Peningkatan kebutuhan masyarakat terhadap pendidikan formal, khususnya pendidikan tinggi, menjadikan perguruan tinggi sebagai sektor strategis yang diharapkan dapat menghasilkan sumber daya manusia yang bermutu. Keadaan persaingan yang cukup kompetitif antara perguruan tinggi menuntut lembaga pendidikan memperhatikan mutu pendidikan dan kelembagaan sehingga mampu serta unggul dalam persaingan tersebut. Keberhasilan program studi sebagai unit kerja dalam perguruan tinggi sangat ditentukan oleh mutu pelayanan yang diberikan, pelayanan yang bermutu dapat diidentifikasi melalui kepuasan pelanggan, dalam hal ini adalah mahasiswa/lulusan. Untuk mencapai tingkat kepuasan yang tinggi, diperlukan pemahaman tentang apa yang diinginkan oleh mahasiswa/lulusan, dengan mengembangkan komitmen setiap orang yang ada dalam lembaga untuk memenuhi kebutuhan mahasiswa/lulusan. Program Studi D-III Kebidanan Sekolah Tinggi Ilmu Kesehatan (STIKes) Respati Tasikmalaya sebagai salah satu lembaga pendidikan tinggi, harus dapat menerapkan konsep mengutamakan kepuasan mahasiswa sebagai pelanggan dengan memberikan kualitas pendidikan terbaik. Beberapa bidang pelayanan yang harus dikembangkan secara berkelanjutan meliputi tatakelola, pengabdian pada masyarakat, kurikulum program studi, proses pembelajaran, sumber daya manusia, suasana akademik, penelitian dan publikasi, kemahasiswaan, keuangan, serta prasarana dan sarana.

Berdasarkan latar belakang di atas, maka peneliti tertarik untuk melakukan penelitian tentang "Pengaruh kualitas pendidikan terhadap kepuasan lulusan di Sekolah Tinggi Ilmu Kesehatan Respati Tasikmalaya". 


\section{Metode}

Jenis penelitian kuantitatif dan metode yang digunakan adalah metode survey analitik dengan desain penelitian yaitu cross sectional. Populasi dalam penelitian ini adalah seluruh lulusan STIKes Respati Tasikmalaya dua tahun terakhir yaitu Angkatan VII dan VIII, karena baru lulus diharapkan lulusan masih mengingat tentang kualitas pendidikan yang didapatkan selama menempuh pendidikan di STIKes dan dapat menilai tingkat kepuasannya. Seluruh lulusan Angkatan VII dan VIII berjumlah 201 lulusan terdiri atas 97 lulusan angkatan VII dan 104 lulusan angkatan VIII.

Populasi penelitian ini terdiri dari dua angkatan yang berbeda, sehingga perlu dilakukan sampling dengan cara simple random sampling. Data penelitian ini adalah hasil dari kuesioner yang disebarkan kepada 106 alumni. Semua pertanyaan yang menyangkut data penelitian telah teruji validitas dan reabilitasnya.

Metode pengumpulan data dalam penelitian ini adalah dengan kuesioner. Sistematika penyebaran kuesioner melalui beberapa tahap:

Tahap I: dilakukan pendataan data lulusan dari bagian kemahasiswa Prodi untuk melacak alamat dan nomor telepon.

Tahap II: menghubungi lulusan untuk dilakukan kontrak waktu pertemuan dengan peneliti, baik dilakukan di STIKes maupun tempat yang telah disepakati.

Tahap III: jika jumlah sampel minimal belum tercapai, maka akan dilakukan kunjungan langsung ke tempat kerja lulusan berdasarkan data yang dimiliki STIKes. Selain itu kuesioner juga akan dikirimkan melalui email maupun kantor pos.

Kualitas pendidikan yang dimaksud dalam penelitian ini merupakan kualitas pendidikan yang berdasarkan pada hasil penelitian yang dilakukan oleh Singgih dan Rahmayanti (2008) bahwa hasil confirmatory factor analysis mempergunakan 10 indikator standar kualitas yang ditetapkan oleh Direktur Jenderal Pendidikan Tinggi (Dirjen DIKTI) ternyata semua indikator tersebut berpengaruh secara signifikan pada kualitas pendidikan. Indikator kualitas pendidikan tersebut adalah proses pembelajaran, kurikulum program studi, sumber daya manusia, kemahasiswaan, prasarana dan sarana, suasana akademik, pembiayaan, penelitian dan publikasi, pengabdian masyarakat, serta tata kelola.

Setelah data diperoleh, maka dilakukan tahap berikutnya yakni tahap Analisis data penelitian. Analisis data penelitian yang digunakan adalah analisis deskriptif, analisis kuadran, dan analisis persamaan model struktural (SEM).

Analisis yang akan digunakan adalah analisis deskriptif, analisis kuadran, dan analisis persamaan model struktural (SEM).

\section{Analisis Deskriptif}

Data yang telah dikumpulkan dari kuesioner selanjutnya diolah. Untuk mengetahui tanggapan terhadap setiap pernyataan yang diajukan dalam kuesioner, maka peneliti akan mendistribusikannya berdasarkan frekuensi setiap jawaban yang diberikan responden. Untuk mengukur tanggapan terhadap variabel yang merupakan pengakumulasian setiap jawaban responden, maka peneliti mengacu pada apa yang dikemukan oleh Panuju $\mathrm{R}$ (2001) yaitu "untuk mengetahui kategori tinggi, sedang, dan rendah maka akan harus diketahui nilai indeks minimum, maksimum, serta jarak intervalnya yaitu sebagai berikut:

1. Setiap indikator yang dinilai oleh responden, diklasifikasikan dalam lima alternatif jawaban dengan menggunakan skala ordinal yang menggambarkan peringkat jawaban. 
2. Dihitung total skor setiap variabel/subvariabel $=$ jumlah skor seluruh indikator variabel untuk semua responden.

3. Dihitung skor setiap variabel $/$ subvariabel $=$ rata-rata total skor.
4. Untuk mendeskripsikan jawaban responden, juga digunakan statistik deskriptif seperti distribusi frekuensi dan tampilan dalam bentuk tabel ataupun grafik dengan bantuan software Excell dan Statistical Product and Service Solutions (SPSS).

\section{Tabel 1. Kriteria Presentase Tanggapan RespondenTerhadap Skor Aktual}

\begin{tabular}{ll}
\hline Persentase Skor & \multicolumn{1}{c}{ Kategori Skor } \\
\hline $20,00-36,00$ & Sangat rendah/tidak baik \\
$36,01-52,00$ & Rendah/kurang baik \\
$52,01-68,00$ & Cukup tinggi/cukup baik \\
$68,01-84,00$ & Tinggi/baik \\
$84,01-100$ & Sangat tinggi/sangat baik \\
\hline
\end{tabular}

Sumber: Narimawati, 2010

Analisis Kuadran

Untuk mengukur skor tingkat kualitas pendidikan dan skor tingkat kepuasan, berdasarkan konsep yang dikembangkan oleh Parasuraman, (194) akan digunakan rumus sebagai berikut:

Service Quality Score $=$ Perception Score - Expectation Score atau

$\mathrm{KL}=\mathrm{P}-\mathrm{H}$

KL: Skor kualitas pendidikan

P: Skor persepsi lulusan
$\mathrm{H}$ : Skor harapan lulusan

Perhitungan tingkat kualitas pendidikan dapat diuraikan sebagai berikut:

$\mathrm{P}-\mathrm{H}=0$ : Berarti tingkat kualitas pendidikan sama dengan harapan lulusan $\mathrm{P}-\mathrm{H}>0$ : Berarti tingkat kualitas pendidikan perguruan tinggi sangat memuaskan lulusan

$\mathrm{P}-\mathrm{H}<0$ : Berarti tingkat pelayanan lebih rendah daripada harapan lulusan

$$
\text { Satisfaction Score } \frac{\text { Perceived Service }}{\text { Expected Service }} \quad \text { Atau } \mathrm{KP}={ }_{\mathrm{H}}^{\mathrm{P}}
$$

KP: $\quad$ Skor kepuasan Lulusan

P: $\quad$ Skor persepsi lulusan

$\mathrm{H}$ : $\quad$ Skor harapan lulusan

Kemudian perhitungan tingkat kepuasan lulusan dapat diuraikan sebagai berikut:

$\mathrm{KP}<1: \quad$ Lulusan tidak puas

$\mathrm{KP}=1: \quad$ Lulusan puas

$\mathrm{KP}>1: \quad$ Lulusan sangat puas

Importance Performance Analysis

Untuk menentukan tingkat kepentingan terhadap atribut dalam dimensi kepuasan lulusan, maka digunakan importance performance analysis atau dikenal dengan istilah lain yaitu analisis tingkat kepentingan dan tingkat kinerja (Arikunto, 1993). Berdasarkan hasil penelitian tingkat kepentingan dan penilaian tingkat pelaksanaan/kinerja maka akan dihasilkan 
suatu perhitungan mengenai tingkat kesesuaian antara tingkat kepentingan dan tingkat pelaksanaan. Tingkat kesesuaian merupakan hasil perbandingan skor pelaksanaan/kinerja dengan skor kepentingan. Tingkat kesesuaian inilah yang akan menentukan urutan prioritas peningkatan faktor-faktor yang memengaruhi kepuasan, dengan menggunakan rumus sebagai berikut:

$\mathrm{TK}_{\mathrm{i}}=\frac{\mathrm{X}_{\mathrm{i}}}{\mathrm{Y}_{\mathrm{i}}} \quad \mathrm{x} 100 \%$

$\mathrm{TK}_{\mathrm{i}}$ : Tingkat kesesuaian responden

$\mathrm{X}_{\mathrm{i}} \quad$ : Skor penelitian pengamatan

$\mathrm{Y}_{\mathrm{i}}$ : Skor peniliaian harapan lulusan

Dalam menyederhanakan rumus, maka untuk mengetahui sikap faktor yang memengaruhi kepuasan lulusan, maka dipakai diagram kartesius sebagai alat. Selanjutnya sumbu mendatar (X) akan diisi dengan skor tingkat pelaksanaa/kenyataan, sedangkan sumbu tegak (Y) akan diisi oleh skor tingkat kepentingan, maka untuk setiap faktor yang memengaruhi kepuasan lulusan menjadi sebagai berikut:

$$
\begin{array}{r}
\bar{X}=\frac{\sum X_{i}}{n} \\
\bar{Y}=\frac{\sum Y_{i}}{n} A
\end{array}
$$

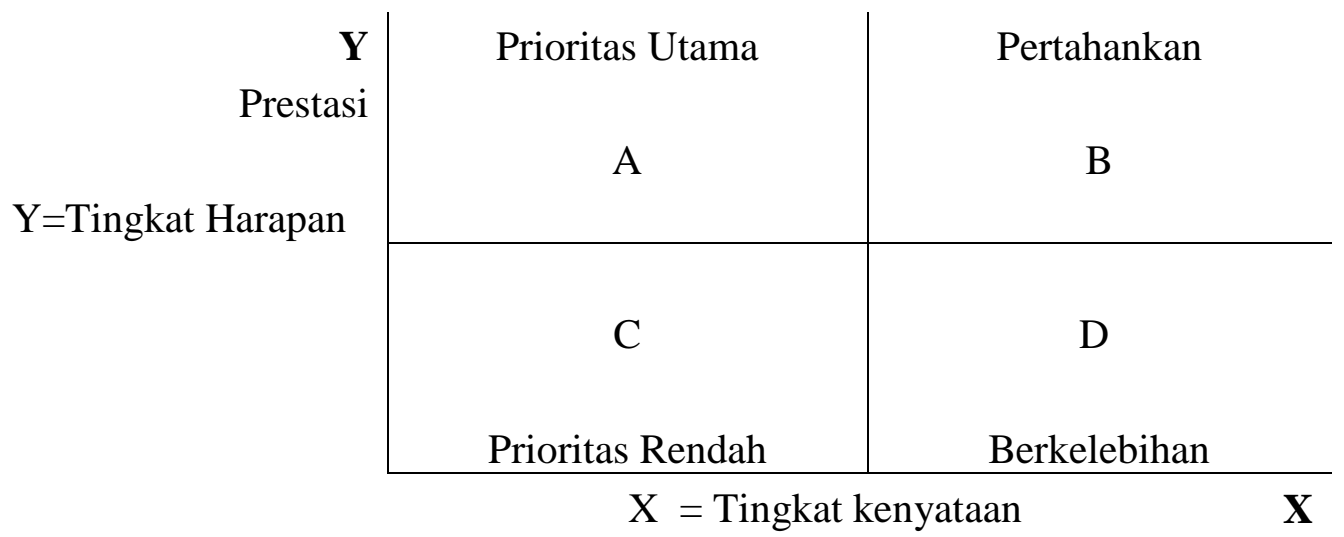

n: Jumlah responden
$\overline{\mathrm{X}}$ : Skor rata-rata tingkat pelaksanaan/ kepuasan

$\bar{Y}$ : Skor rata-rata tingkat kepentingan

Diagram kartesius merupakan suatu kuadran yang dibagi atas empat bagian yang dibatasi oleh dua buah garis yang berpotongan tegak lurus pada tit $(\overline{\overline{\mathrm{X}}}, \overline{\bar{Y}}) \mathrm{ik}$ $\bar{X}$ merupakan rata-rata dari rata-rata tingkat pelaksanaan atau kepuasan lulusan seluruh faktor atau atribut, dan $\overline{\bar{Y}}$ adalah rata-rata dari rata-rata skor tingkat kepentingan seluruh faktor yang memengaruhi kepuasan lulusan, dengan rumus lanjutan sebagai berikut:

$$
\begin{gathered}
=\frac{\sum i^{n}=1 \mathrm{X}}{\mathrm{X}}=\frac{\mathrm{k}}{\mathrm{K}} \\
Y=\frac{\sum \mathrm{i}^{\mathrm{n}}=1 \mathrm{Y} i}{\mathrm{~K}}
\end{gathered}
$$

K: banyaknya atribut/fakta yang dapat memengaruhi kepuasan lulusan

Selanjutnya, tingkat unsur-unsur tersebut akan dijabarkan dan dibagi menjadi empat bagian ke dalam diagram kartesius seperti terlihat pada gambar berikut ini:

Pertahankan

B $\mathbf{X}$

\section{Gambar 1 Diagram Kartesius}


Keterangan:

A = Menunjukkan faktor atau atribut yang dianggap memengaruhi kepuasan lulusan, termasuk indikator kepuasan lulusan yang dianggap penting namun manajemen belum melaksanakan sesuai keinginan lulusan.

$\mathrm{B}=$ Menunjukkan kepuasan lulusan yang telah berhasil dilaksanakan perguruan tinggi, untuk itu wajib dipertahankan

$\mathrm{C}=$ Menunjukkan beberapa faktor yang kurang penting pengaruhnya bagi kepuasan lulusan, pelaksanaannya oleh perguruan tinggi biasa-biasa saja, dianggap kurang penting dan kurang memuaskan

$\mathrm{D}=$ Menunjukkan faktor yang memengaruhi lulusan yang kurang penting, tetapi pelaksanaannya terlalu berlebihan, dianggap kurang penting tetapi sangat memuaskan bagi lulusan.

\section{Structural Equation Model (SEM)}

Penelitian ini bermaksud melakukan pengujian hubungan variabel kualitas pendidikan dalam kaitannya dengan kepuasan lulusan. Adapun teknik analisis yang digunakan adalah analisis structural equation modelling (SEM) atau model persamaan struktural. Pemilihan metode ini dilakukan karena SEM cocok untuk penelitian pengaruh antara variable; variabel yang diteliti tidak secara langsung dapat diamati, melainkan harus diterangkan oleh subvariabel atau dimensi dan indikatornya (Ferdinand, 2000).

Model struktural adalah model yang menjelaskan hubungan kausal antara variabel laten independen dan variabel laten dependen, sedangkan model pengukuran, model deskriptif atau model analisis faktor konfirmatori adalah model yang menjelaskan operasionalisasi variabel laten independen dan dependen menjadi variabel atau indikator-indikatornya dapat diobservasi secara langsung.
Langkah-langkah yang akan dilakukan dalam analisis ini adalah:

1. Transformasi Data

Setiap pernyataan diukur dengan skala Likert dengan 5 (lima) kategori jawaban (respons) dan arah jawaban yang positif. Sebelum dilakukan pendugaan atau estimasi terlebih dahulu dilakukan peningkatan skala. Langkah-langkah metode tersebut adalah sebagaimana dijelaskan oleh Al-Rasyid (1994) sebagai berikut:

a. Perhatikan setiap butir pernyataan

b. Untuk setiap butir tersebut tentukan berapa orang yang mendapat skor 1,2,3,4,5 yang disebut dengan frekuensi

c. Setiap frekuensi dibagi dengan banyaknya responden dan hasilnya disebut proporsi

d. Tentukan proporsi komulatif

e. Dengan menggunakan tabel distribusi normal, hitung nilai $\mathrm{z}$ untuk setiap proporsi komulatif yang diperoleh

f. Tentukan nilai densitas untuk setiap nilai $\mathrm{z}$ yang diperoleh (dengan menggunakan tabel densitas)

Setelah data ditingkatkan skala pengukurannya ke dalam interval, dilakukan analisis dengan menggunakan SEM. Pemodelan LISREL dibangun berdasarkan teori, hasil penelitian, dan fakta. Langkah-langkah pemodelan sebagai berikut:

2. Konseptualisasi model

Konseptualisasi model akan disusun hipotesis yang berdasarkan teori, hasil penelitian dan fakta sebagai pedoman untuk menyusun hubungan variabel laten terhadap variabel laten lain dan juga variabel-variabel indikatornya. 
3. Pembentukan diagram jalur

4. Spesifikasi Model

Tahap spesifikasi model pada dasarnya merupakan suatu proses perumusan ke dalam notasi-notasi matematika, misalnya dari model yang bersifat verbalistik ke dalam model statistik, banyaknya parameter yang ditaksir dan notasi-notasi yang sesuai dengan program komputer.

5. Metode Estimasi

Setelah identifikasi model dan model dinyatakan over identified, langkah selanjutnya adalah estimasi parameter. Dalam penelitian ini, metode penaksiran yang digunakan yaitu metode maximum likelihood $(M L)$.

\section{Kecocokan Model}

Ukuran-ukuran kesesuaian dalam model persamaan struktural dapat dilakukan secara inferensial atau deskriptif. Statistik chi-kuadrat dapat digunakan untuk menguji kesesuaian model secara inferensial, sedangkan ukuran kesesuaian secara deskriptif yang dinyatakan dalam suatu indeks, misalnya yang sering digunakan adalah goodness of fit indices (GFI), adjusted goodness of fit indices (AGFI).

Langkah pengujiannya sebagai berikut:

7. Hipotesis pengujian

$H_{0}: \Sigma=\Sigma(\theta)$ Model fit dengan data

$H_{1}: \Sigma \neq \Sigma(\theta)$ Model tidak fit dengan data

8. Statistik Uji

$$
\chi^{2}=(n-1) \times F(\hat{\theta})
$$

\section{Kriteria Uji}

Terima $\mathrm{HO}$ jika nilai peluang nilai $\mathrm{p}$ lebih besar dari $\alpha$.

Sementara pengujian secara deskriptif dapat dilakukan dengan fit index dalam Tabel 2 sebagai berikut:

Tabel 2. Statistik-Statistik Uji Kecocokan Model

\begin{tabular}{ll}
\hline \multicolumn{1}{c}{ Statistik Uji Kecocokan Model } & \multicolumn{1}{c}{ Interpretasi } \\
\hline $\begin{array}{l}\text { Goodness of-Fit Indices (GFI) } \\
\text { Root Mean Squared Residual }\end{array}$ & Nilai $>0,9$ menunjukkan good fit \\
(RMR) & Nilai menunjukkan good fit \\
Root Mean Square Error of & Nilai kurang dari 0,05 menunjukkan \\
Approximation (RMSEA) & good fit \\
$\begin{array}{l}\text { Adjusted Goodness of Fit (AGFI) } \\
\text { Normed Fit Index (NFI) }\end{array}$ & Nilai > 0,9 menunjukkan good fit \\
Non-Normed Fit Index (NNFI) & Nilai $>0,9$ menunjukkan good fit \\
Normed Chi-Square (NC) & Kurang dari 1 (model jelek), lebih \\
& dari 5 (model perlu modifikasi) \\
Comparative Fit Index (CFI) & Nilai >0,9 menunjukkan good fit \\
Incremental Index Fit (IIF) & Semakin tinggi nilai IIF, semakin fit \\
& suatu model dengan data \\
\hline
\end{tabular}

10. Analisis Model Pengukuran

Setelah kecocokan model dan data secara keseluruhan adalah baik, langkah berikutnya adalah evaluasi atau analisis model pengukuran. Evaluasi ini dilakukan terhadap setiap model pengukuran atau konstruk secara terpisah melalui evaluasi terhadap validasi (validity) dari model pengukuran dan evaluasi terhadap reliabilitas (reability) dari model pengukuran.

Validitas berhubungan dengan apakah suatu variabel mengukur apa yang seharusnya diukur. Reliabilitas 
menyangkut konsistensi atau stabilitas suatu alat ukur. Suatu alat ukur dapat dikatakan konsisten jika alat tersebut digunakan dalam waktu yang berbeda dan dalam kondisi yang relatif sama akan menghasilkan hasil yang relatif sama pula. Reliabilitas tinggi menunjukkan bahwa indikator-indikator mempunyai konsistensi tinggi dalam mengukur konstruk latennya.

a) Evaluasi terhadap validitas (validity) model pengukuran

Suatu variabel dikatakan mempunyai validitas yang baik terhadap kostruk atau variabel latennya, jika nilai-t muatan faktornya (factor loading) lebih besar dari nilai kritis (t tabel)

b) Evaluasi terhadap reliabititas (reliability) model pengukuran

Untuk mengukur reabilitas dalam SEM kita dapat menggunakan: composite reability measure (ukuran reabilitas komposit)dan variance extracted measure (ukuran ekstrak varian).

Reliabilitas komposit suatu konstruk dihitung sebagai:

$$
\text { Construct.reliability }=\frac{\left(\sum \text { std.loading }\right)^{2}}{\left(\sum \text { std.loading }\right)^{2}+\sum e_{j}}
$$

Keterangan:
Std.loading: Koefisien bobot faktor yang distandar (standardized loading) untuk setiap indikator

$\mathrm{e}_{\mathrm{j}} \quad$ : Kesalahan pengukuran (measuremant error) untuk setiap variabel manifest.

Nilai Construct Reliability (CR) di atas 0,70 menunjukkan bahwa indikatorindikator tersebut reliable untuk mengukur konstruk tersebut.

Pengujian Hipotesis

Pengujian terhadap hipotesis yang telah dikemukakan sebelumnya akan dilakukan dengan uji-t, yaitu membandingkan $t$ hitung dengan $t$ tabel.

$\mathrm{H}_{0}: \square=0 \quad$ (kualitas pendidikan tidak berpengaruh pada kepuasan lulusan)

$\mathrm{H}_{1}: \square \square 0 \quad$ (kualitas pendidikan berpengaruh pada kepuasan lulusan)

Statistik uji:

$$
\begin{aligned}
& \quad t_{\text {hitung }}=\frac{\hat{\gamma}}{s(\hat{\gamma})} \sim \mathrm{t}_{(\square / 2, \mathrm{n}-\mathrm{k}-1)} \\
& \text { Kriteria Penolakan dan Penerimaan } \\
& \text { Hipotesis Nol } \\
& \text { Tolak hipotesis nol jika t hitung }>\mathrm{t} \text { tabel } \\
& \text { atau }-\mathrm{t} \text { hitung }<-\mathrm{t} \text { tabel atau nilai } \mathrm{p}< \\
& 0,05 \\
& \text { Terima hipotesis nol jika }-\mathrm{t} \text { tabel }<\mathrm{t} \\
& \text { hitung }<\mathrm{t} \text { tabel atau jika } \mathrm{p} \text {-value }>0,05
\end{aligned}
$$

\section{Hasil Penelitian}

Tabel 3. Deskripsi Responden

\begin{tabular}{lll}
\hline Karakteristik & $\mathbf{n}$ & \% \\
\hline Lama menunggu pekerjaan (bulan) & & \\
$\leq 3$ & 69 & 65,1 \\
$>3-6$ & 32 & 30,2 \\
$\quad \geq 6-12$ & 5 & 4,7 \\
Sumber informasi pekerjaan & & \\
$\quad$ Media cetak & 1 & 0,9 \\
Teman & 31 & 29,3 \\
Media elektronik & 1 & 0,9 \\
Almamater/Fakultas & 4 & 3,8 \\
$\quad$ Orangtua/saudara & 57 & 53,8 \\
$\quad$ Lainnya..... & 12 & 11,3 \\
Pekerjaan pertama & & \\
$\quad$ Pelayanan kesehatan & 105 & 99,1 \\
$\quad$ Nonpelayanan kesehatan & 1 & 0,9
\end{tabular}




\section{Pekerjaan saat ini}

Pelayanan kesehatan

$\begin{array}{ll}84 & 79,3 \\ 22 & 20,7\end{array}$

Nonpelayanan kesehatan

Keterkaitan pekerjaan dengan bidang kebidanan

Ya

$100 \quad 94,3$

Tidak

$6 \quad 5,7$

\section{Kesesuaian materi}

Terpenuhi

$94 \quad 88,7$

Cukup

\section{Gaji pertama (Rp.)}
$\leq 1$ juta
$89 \quad 84,0$
$\geq 1-3$ juta
$17 \quad 16,0$

Gaji saat ini

\begin{tabular}{llr}
$1-2$ juta & 104 & 98,1 \\
$3-4$ juta & 2 & 1,9 \\
\hline
\end{tabular}

Berdasarkan Tabel 3 terlihat bahwa dari 106 lulusan STIKes Respati Tasikmalaya, lebih dari setengah lulusan memiliki waktu menunggu pekerjaan kurang dari 3 bulan $(65,1 \%)$. Jika dilihat dari sumber informasi yang didapat, lebih dari setengahnya $53,8 \%$ didapat dari orangtua atau saudara. Sebagian besar lulusan saat ini $(79,3 \%)$ bekerja pada pelayanan kesehatan.
Dilihat dari kesesuaian materi dengan pekerjaan sekarang, didapat bahwa sebagian besar merasa materi telah terpenuhi $(88,7 \%)$. Gaji pertama yang didapat berkisar kurang dari 1 juta pada awal bekerja, sedangkan gaji saat ini yang didapat sebagian besar $(98,1 \%)$ memiliki gaji 1-2 juta rupiah.

\section{Tabel 4. Uji Normalitas}

\begin{tabular}{|c|c|c|c|c|c|c|c|c|}
\hline Variabel & Min & Maks & $\begin{array}{l}\text { Rata- } \\
\text { rata }\end{array}$ & $\begin{array}{l}\text { Std. } \\
\text { Deviasi }\end{array}$ & Skew & c.r & kurtosis & c.r. \\
\hline $\begin{array}{l}\text { Kualitas } \\
\text { pendidikan }\end{array}$ & 22,10 & 44,60 & 35,31 & 5,02 & $-0,26$ & $\begin{array}{l}- \\
1,10\end{array}$ & $-0,45$ & 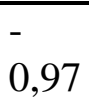 \\
\hline $\begin{array}{l}\text { Kepuasan } \\
\text { lulusan }\end{array}$ & 12,70 & 22,70 & 17,47 & 3,29 & 0,22 & 0,91 & $-0,66$ & $\begin{array}{l}- \\
1,85\end{array}$ \\
\hline
\end{tabular}

Perhitungan normalitas data dilakukan dengan cara membagi nilai Skewness dengan standar errornya yang mengasilkan nilai c.r. atau nilai Kurtosis dibagi standar errornya, jika hasil perhitungan berada diantara -2 sampai dengan +2 , maka dapat dikatakan data berdistribusi normal.
Berdasarkan tabel di atas dapat dilihat bahwa data kualitas pendidikan dan kepuasan lulusan berdistribusi normal karena memiliki nilai antara -2 sampai dengan 2 .

Tabel 5. Gambaran Kualitas Pendidikan

\begin{tabular}{llllllll}
\hline \multirow{2}{*}{ Variabel } & \multirow{2}{*}{ Indikator } & \multicolumn{2}{l}{ Kategori } & \multicolumn{3}{c}{ Skor } \\
\cline { 3 - 7 } & & SB & B & C & K & SK & \\
\hline Kualitas & Proses Pembelajaran & 41 & 38 & 27 & 0 & 0 & 4,13 \\
pendidikan & Kurikulum Program Studi & 0 & 106 & 0 & 0 & 0 & 4,00 \\
\hline
\end{tabular}


(X)

\begin{tabular}{lllllll} 
Sumber Daya Manusia & 31 & 18 & 52 & 1 & 4 & 3,67 \\
Kemahasiswaan & 2 & 44 & 50 & 6 & 4 & 3,32 \\
Prasarana dan Sarana & 0 & 16 & 79 & 11 & 0 & 3,05 \\
Suasana Akademik & 26 & 21 & 53 & 6 & 0 & 3,63 \\
Keuangan & 32 & 12 & 21 & 35 & 6 & 3,27 \\
Penelitian dan Publikasi & 2 & 29 & 65 & 10 & 0 & 3,22 \\
Pengabdian pada masyarakat & 30 & 38 & 25 & 10 & 3 & 3,77 \\
Tatakelola & 31 & 21 & 54 & 0 & 0 & 3,78 \\
\hline Total & 195 & 343 & 426 & 79 & 17 & 3,58 \\
\hline
\end{tabular}

Berdasarkan hasil perhitungan, didapat bahwa untuk proses belajar dinilai dengan kategori sangat baik paling tinggi diantara yang lainnya. Sementara untuk indikator kurikulum program studi dinilai baik oleh semua lulusan (106 lulusan), Untuk indikator prasaran dan sarana, penelitian dna publikasi dan keuangan lebih banyak dinilai dengan kategori cukup dan kurang.

Jika dilihat dari skor rata-rata tiap indikator, didapat bahwa dari 10 indikator kualitas, indikator yang paling tinggi nilainya, yaitu sebesar 4,13.Selanjutnya adalah indikator kurikulum program studi sebesar 4,00, indikator pengabdian pada masyarakat sebesar 3,78. Sementara itu, terdapat 3 indikator yang masih dinilai rendah oleh para lulusan, yaitu prasarana dan sarana dengan skor 3,05; penelitian dan publikasi dengan skor 3,22; dan keuangan atau biaya perkuliahan dengan skor 3,27 .

Tabel 6. Gambaran Kualitas Pendidikan

\begin{tabular}{llllllll}
\hline No & Pernyataan & $\begin{array}{l}\text { Penilaian } \\
\text { Kenyataan }\end{array}$ & $\begin{array}{l}\text { Penilaian } \\
\text { Harapan }\end{array}$ & $\bar{x}$ & $\bar{y}$ & $\begin{array}{l}\text { TKR } \\
(\%)\end{array}$ & $\begin{array}{l}\text { Tsi } \\
(\%)\end{array}$ \\
\hline \multicolumn{2}{l}{ Kepuasan lulusan } & & & & & & \\
\hline 1 & $\begin{array}{l}\text { Kualitas } \\
\text { produk }\end{array}$ & 1204 & 1508 & 3,79 & 4,74 & 79,84 & 20,16 \\
& $\begin{array}{l}\text { Kualitas } \\
\text { pelayanan }\end{array}$ & 1587 & 2015 & 3,74 & 4,75 & 78,76 & 21,24 \\
& $\begin{array}{l}\text { Faktor } \\
\text { emosional }\end{array}$ & 1113 & 1508 & 3,50 & 4,74 & 73,81 & 26,19 \\
4 & Biaya & 565 & 1017 & 2,67 & 4,80 & 55,56 & 44,44 \\
5 & Harga & 399 & 500 & 3,76 & 4,72 & 79,80 & 20,20 \\
\hline
\end{tabular}

\section{Rata-rata Umum}

Skor yang diberikan oleh lulusan baik pada penilaian kenyataan dan harapan berkisar antara 1-5, sehingga skor 3 dapat dijadikan batasan untuk menentukan penilaian negatif atau positif. Penilaian yang positif adalah penilaian yang lebih dari 3, dan sebaliknya penilaian negatif yang kurang dari 3. Hasil perhitungan pada tabel di atas menunjukkan bahwa skor rata-rata persepsi lulusan paling tinggi pada kualitas produk, yang ditunjukkan dengan skor 3,79; selanjutnya pada
iBd4gator harga 4,85esar 3,76. Sementara itu, skor penilaian kenyataan paling kecil ada pada indikator biaya $(2,67)$ yang dinilai dengan persepsi yang negatif.

Dari hasil perhitungan nilai kesenjangan dapat dilihat bahwa untuk indikator biaya memiliki tingkat kesenjangan paling tinggi antara harapan dan kenyataan, tingkat kesenjangan tersebut mencapai 44,44\%. Sementara indikator yang lainnya dengan tingkat kesenjangan kurang dari 30\%. Tingkat kesenjangan paling kecil adalah indikator kualitas produk sebesar 20,16\%. 


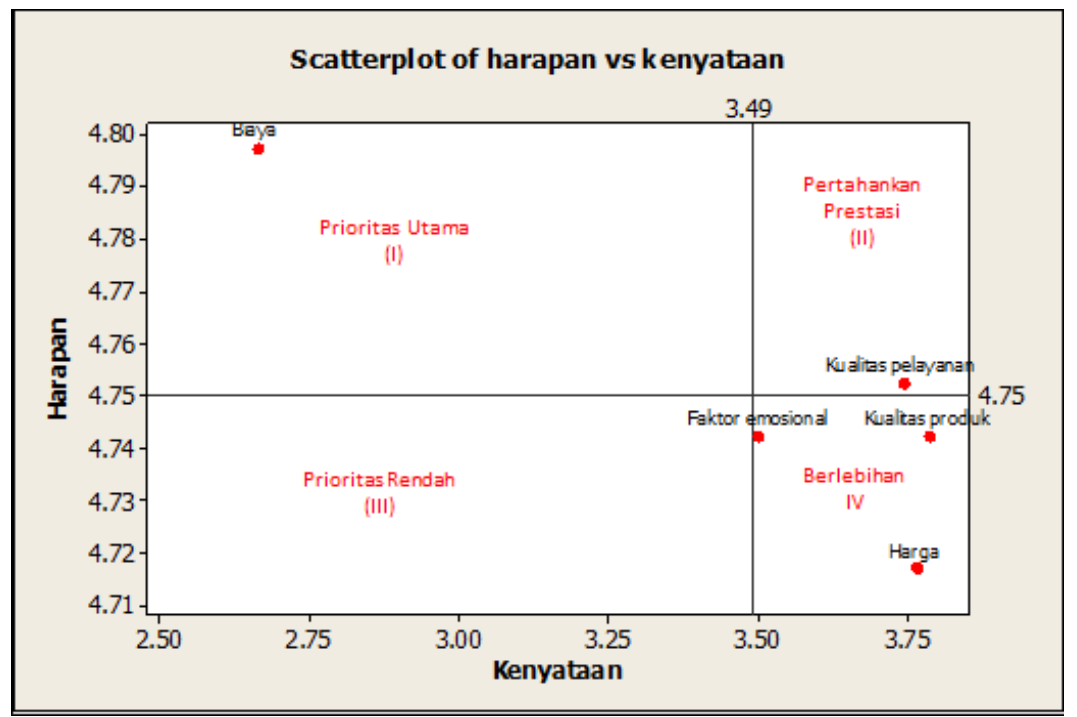

\section{Gambar 2. Hasil Analisis Kuadran}

Berdasarkan hasil analisis kuadran diagram kartesius pada Gambar 2 didapatkan hasil bahwa indikator yang terdapat pada kuadran I merupakan unsurunsur jasa yang dianggap penting, namun manajemen belum melaksanakannya sesuai keinginan lulusan sehingga mengecewakan/tidak puas. Indikator yang berada pada kuadran satu tersebut yaitu biaya. Indikator yang terdapat pada kuadran IV merupakan indikator yang memengaruhi lulusan kurang penting, akan tetapi pelaksanaannya berlebihan. Indikator yang dianggap kurang penting tetapi sangat memuaskan, antara lain harga, kualitas produk, dan faktor emosional.

Tabel 7. Hubungan antara Kualitas Pendidikan Dengan Kepuasn Lulusan StiKes Respati Tasikmalaya

\begin{tabular}{llllll}
\hline Variabel & R & thitung & $\begin{array}{l}\boldsymbol{p} \text { - } \\
\text { value }\end{array}$ & Keterangan & Kesimpulan \\
\hline $\begin{array}{l}\text { Kualitas Pendidikan } \\
\text { (X) dengan Kepuasan }\end{array}$ & 0,455 & 5,211 & 0,000 & Ho Ditolak & $\begin{array}{l}\text { Terdapat } \\
\text { Lulusan (Y) }\end{array}$ \\
\hline
\end{tabular}

Pada tabel di atas dapat dilihat koefisien korelasi adalah sebesar 0,455. Hasil uji signifikansi diperoleh nilai $\mathrm{t}$ hitung sebesar 5,211 dan nilai t tabel dengan $\alpha=5 \%$ adalah sebesar 2,002, maka dapat dilihat bahwa t hitung $(5,211)$ $>$ t tabel $(1,984)$ atau p-value $(0,000)<\alpha$ $(0,05)$ sehingga Ho ditolak. Dengan demikian dapat disimpulkan bahwa terdapat hubungan antara kualitas pendidikan $(\mathrm{X})$ dengan kepuasan lulusan (Y). Koefisien korelasi yang positif menunjukkan bahwa semakin baik kualitas pendidikan (X) maka semakin baik pula kepuasan lulusan (Y). Dengan menggunakan kriteria Guildford, koefisien korelasi sebesar 0,455 menunjukkan bahwa hubungan antara dengan kepuasan lulusan (Y) merupakan hubungan yang sedang.

Pengaruh Kualitas Pendidikan (X) terhadap Kepuasan Lulusan (Y)

Untuk mengetahui pengaruh kualitas pendidikan terhadap kepuasn lulusan StiKes Respati Tasikmalaya, peneliti menggunakan analisa Structural Equation Model (SEM). 
Analisis Model Keseluruhan (Overall Model)

Pengujian kesesuaian model keseluruhan yang diusulkan. Dari Goodness of fit Statistics pada table 8 dapat dinyatakan bahwa kriteria RMR menghasilkan kesimpulan Good Fit. Selainnya dengan acceptable fit dan not fit.
Dari kombinasi berbagai ukuran kecocokan tersebut, secara umum dapat disimpulkan bahwa kecocokan keseluruhan model pada penelitian ini adalah cukup baik sehingga model dapat diinterpretasi lebih lanjut.

Tabel 8. Indeks Goodness of Fit pada Model Penelitian SEM

\begin{tabular}{|c|c|c|c|c|}
\hline \multirow{2}{*}{ Kriteria } & \multicolumn{2}{|l|}{ Nilai Kritis } & \multirow{2}{*}{$\begin{array}{l}\text { Evaluasi } \\
\text { Model }\end{array}$} & \multirow{2}{*}{$\begin{array}{l}\text { Hasil } \\
\text { Analisis }\end{array}$} \\
\hline & Good Fit & Acceptable Fit & & \\
\hline$\chi^{2}$ & \multicolumn{2}{|l|}{$\leq \chi 2$ table $(112.02)$} & 225,13 & Not Fit \\
\hline Pvalue & $0.05<\mathrm{P}<1.00$ & $0.01<\mathrm{P}<0.05$ & 0,000 & Not Fit \\
\hline$\chi^{2 / \mathrm{df}}$ & $0 \leq \chi 2 / \mathrm{df} \leq 2$ & $2 \leq \chi 2 / \mathrm{df} \leq 3$ & 2,530 & $\begin{array}{l}\text { Acceptable } \\
\text { Fit }\end{array}$ \\
\hline RMSEA & $\begin{array}{l}0 \leq \mathrm{RMSEA} \leq \\
0.05\end{array}$ & $0.05<\mathrm{RMSEA} \leq 0.08$ & 0,12 & Not Fit \\
\hline $\begin{array}{l}\text { Confidence } \\
\text { Interval (CI) }\end{array}$ & $\begin{array}{l}\text { close to RMSEA, } \\
\text { left boundary of } \\
\mathrm{CI}=0.00\end{array}$ & close to RMSEA & $\begin{array}{l}(0.10 \\
0.14)\end{array}$ & $\begin{array}{l}\text { Acceptabel } \\
\text { Fit }\end{array}$ \\
\hline RMR & $0 \leq \mathrm{RMR} \leq 0.05$ & $0.05<\mathrm{RMR} \leq 0.07$ & 0,041 & Good Fit \\
\hline NFI & $0.95 \leq \mathrm{NFI} \leq 1.00$ & $0.90<\mathrm{NFI} \leq 0.95$ & 0,9 & $\begin{array}{l}\text { Acceptable } \\
\text { Fit }\end{array}$ \\
\hline CFI & $0.97 \leq \mathrm{CFI} \leq 1.00$ & $0.90<\mathrm{CFI} \leq 0.97$ & 0,94 & $\begin{array}{l}\text { Acceptable } \\
\text { Fit }\end{array}$ \\
\hline GFI & $0.90 \leq \mathrm{GFI} \leq 1.00$ & $0.80<\mathrm{GFI} \leq 0.90$ & 0,87 & $\begin{array}{l}\text { Acceptable } \\
\text { Fit }\end{array}$ \\
\hline
\end{tabular}

Analisis Model Pengukuran

Berikut ini adalah gambar dan tabel yang menunjukkan nilai muatan faktor standar (standardized loading factor) dan kesalahan pengukuran (measurement error) untuk model pengukuran (measurement model) pada masing-masing variabel dengan menggunakan Structural Equation Model. Terdapat 2 (dua) variabel pada penelitian ini, yaitu kualitas pendidikan dan kepuasan lulusan. Berikut hasil pengolahan analisis dengan menggunakan LISREL 8.80 . 


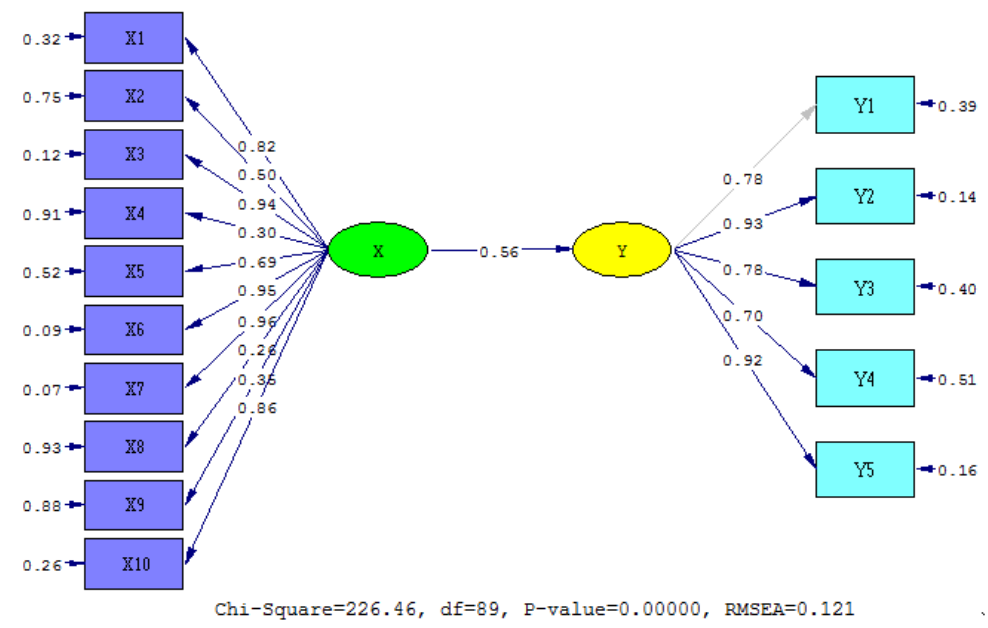

Gambar 3. Standardized Loading Factor pada Structural Equation Model (SEM)

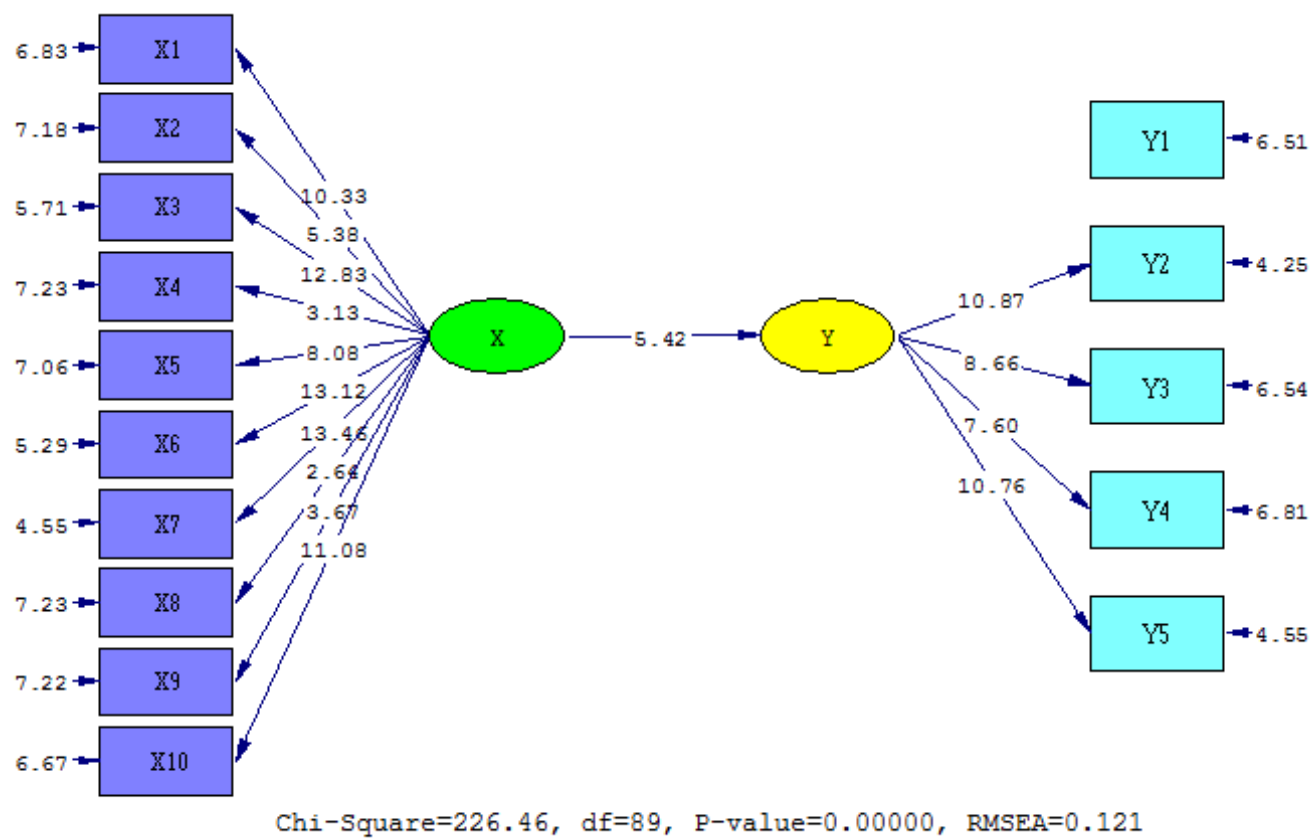

Gambar 4. Uji t pada Structural Equation Model (SEM)

Tabel 9. Analisis Model Pengukuran

\begin{tabular}{|c|c|c|c|c|c|c|}
\hline \multicolumn{2}{|c|}{ Indikator } & $\begin{array}{l}\text { Construct } \\
\text { Reliability }\end{array}$ & $\begin{array}{l}\text { Standardized } \\
\text { Loading }\end{array}$ & $\mathbf{t}$ hitung & t table & Ket \\
\hline \multicolumn{7}{|c|}{ Variabel Kualitas } \\
\hline $\mathrm{X} 1$ & Proses Pembelajaran & \multirow{7}{*}{0,9} & 0,82 & 10,3 & 1,98 & Valid \\
\hline $\mathrm{X} 2$ & Kurikulum Program Studi & & 0,51 & 5,48 & 1,98 & Valid \\
\hline X3 & Sumber Daya Manusia & & 0,94 & 12,9 & 1,98 & Valid \\
\hline $\mathrm{X} 4$ & Kemahasiswaan & & 0,3 & 3,16 & 1,98 & Valid \\
\hline X5 & Prasarana dan Sarana & & 0,69 & 8,08 & 1,98 & Valid \\
\hline X6 & Suasana Akademik & & 0,95 & 13,13 & 1,98 & Valid \\
\hline $\mathrm{X} 7$ & Keuangan & & 0,96 & 13,44 & 1,98 & Valid \\
\hline
\end{tabular}




\begin{tabular}{|c|c|c|c|c|c|c|}
\hline $\mathrm{X} 8$ & Penelitian dan Publikasi & & 0,26 & 2,68 & 1,98 & Valid \\
\hline X9 & Pengabdian pada masyarakat & & 0,35 & 3,7 & 1,98 & Valid \\
\hline $\mathrm{X} 10$ & Tatakelola & & 0,86 & 11,1 & 1,98 & Valid \\
\hline \multicolumn{7}{|c|}{ Variabel Kepuasan } \\
\hline $\mathrm{Y} 1$ & Kualitas produk & & 0,51 & - & 1,98 & Valid \\
\hline $\mathrm{Y} 2$ & Kualitas pelayanan & & 0,83 & 5,29 & 1,98 & Valid \\
\hline $\mathrm{Y} 3$ & Faktor emosional & 0,91 & 0,61 & 4,55 & 1,98 & Valid \\
\hline Y4 & Biaya & & 0,64 & 4,67 & 1,98 & Valid \\
\hline Y5 & Harga & & 0,92 & 5,44 & 1,98 & Valid \\
\hline
\end{tabular}

Pada table 9 serta gambar 3 dan 4 diatas, menunjukkan nilai Standar loading factor (SLF) pada masing-masing indikator terhadap pada model tersebut membuktikan bahwa pada model pengukuran CFA variabel kualitas pendidikan mempunyai validitas yang baik pada masing-masing indikator. Hal ini berdasarkan kriteria validitas yang baik, dimana nilai $\mathrm{t}$ hitung muatan faktornya lebih besar dari t tabel t tabel. Sehingga dapat disimpulkan bahwa indikator pada model pengukuran CFA dapat mengukur variabel kualitas pendidikan dan kepuasan lulusan dapat diukur dengan baik.

Setelah melihat bahwa masing-masing indikator pada variabel mempunyai validitas yang baik, dengan menggunakan nilai standardized loading factor (lamda) pada gambar diatas guna melihat pengaruh langsung masing-masing indikator pada variabelnya. Pada variabel kualitas pendidikan terlihat bahwa indikator keuangan merupakan indikator yang paling dominan, hal ini terlihat indikator tersebut sebesar 0.96. Selanjutnya indikator suasana akademik $(0,95)$ dan sumber daya manusia $(0,94)$. Sementara indikator lainnya seperti pengabdian masyarakat $(0,35)$, kemahasiswaan $(0,30)$ dan penelitian dan publikasi $(0,26)$ dirasa belum memiiliki pengaruh besar pada terbentuknya persepsi kualitas pendidikan.

\section{Analisis Model Struktural}

Dari model struktural dapat diketahui bagaimana pengaruh antar variabel laten, dalam hal ini yaitu analisis pengaruh kualitas pendidikan terhadap kepuasan lulusan di StiKes Respati Tasikamalaya. Berdasarkan hasil output LISREL pada lampiran, berikut ini adalah tabel yang menunjukan hasil estimasi parameter Standaridized (nilai bobot) model struktural untuk model tersebut.

Tabel 10. Paramater Estimasi Standardized Model Struktural Ekosgen ke Endogen

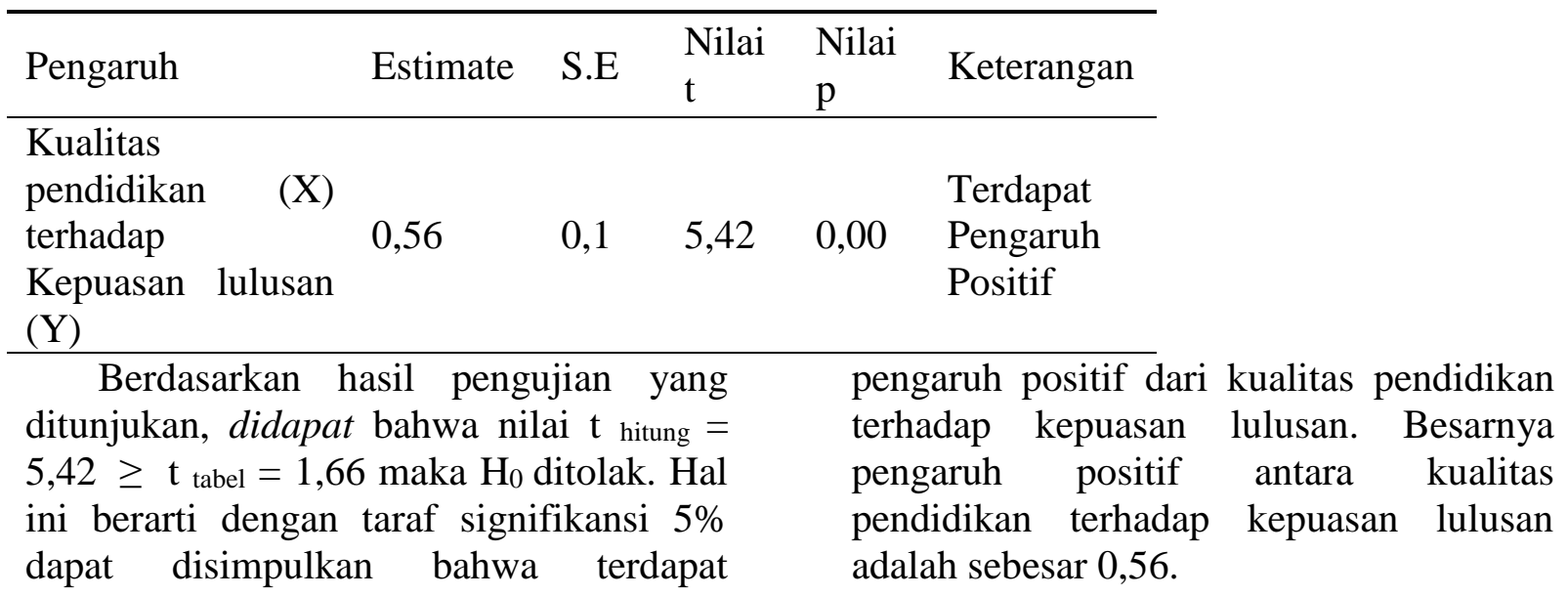




\section{E. Pembahasan}

Pada bagian ini akan menguraikan dan menganalisa data yang diperoleh peneliti dari angket yang telah disebarkan kepada responden sebagai sumber data primer. Adapun data lain diperoleh melalui wawancara, pengamatan atau observasi, dan studi pustaka yang digunakan peneliti sebagai data sekunder atau penunjang guna melengkapi dan memperluas data utama.

Data penelitian ini adalah hasil dari kuesioner yang disebarkan kepada 106 responden. Semua pertanyaan yang menyangkut data penelitian telah teruji validitas dan reabilitasnya (data terlampir). Sampel diperoleh dengan simple random sampling dengan target penelitian ini adalah lulusan STIKes Respati Tasikmalaya angkatan VII dan VIII. Analisis yang akan disajikan terdiri dari dua bagian, yaitu analisis data responden dan analisis kuadran serta analisis SEM untuk melihat pengaruh kualitas mutu pendidikan terhadap kepuasan alumni Stikes Respati. Teknik analisis yang digunakan pada analisis data responden dan data penelitian adalah analisis deskriptif, dimana semua data yang diperoleh disusun ke dalam tabel melalui perhitungan distribusi frekuensi dan persentasenya.

Hasil analisis deskriptif data responden pada Tabel 1 menunjukkan bahwa lama menunggu pekerjaan lulusan masih banyak yang >3-6 bulan sebesar $30,2 \%$ dan sumber informasi pekerjaan lebih banyak didapatkan dari orangtua atau saudara sebesar 53,8\%, sedangkan almamater/fakultas hanya 3,8\%. Hal ini menunjukkan bahwa STIKes perlu meningkatkan peran sertanya dalam memberikan informasi tentang lowongan pekerjaan kepada lulusannya.

Menurut ketua Pengurus Pusat Ikatan Bidan Indonesia (PP IBI) Dr. Harni Koesno, MKM. kampus yang memiliki jurusan kebidanan terus menjamur, sehingga jumlah bidan semakin meningkat. Diperkirakan pada tahun 2015 Indonesia akan mengalami peningkatan jumlah bidan dan sebagian harus dikirim ke luar negeri. Untuk memberdayakan bidan yang jumlahnya berlimpah itu, Dr. Harni telah bekerjasama dengan Badan Nasional Penempatan dan Perlindungan TKI (BNP2TKI) untuk mengirim sebagian bidan ke luar negeri. Salah satu negara yang menjadi tujuan pengiriman adalah Timor Leste (Pramudiardja, 2012).

Beberapa usaha yang perlu dilakukan program studi untuk memberikan informasi lowongan pekerjaan kepada lulusannya sebagai berikut: memberikan informasi tentang kesempatan bekerja di berbagai instansi pemerintah/swasta kepada lulusan, membentuk wadah untuk mengumpulkan informasi tentang kesempatan kerja, membantu lulusan memperoleh pekerjaan, mengundang pihak yang memerlukan tenaga lulusan ke kampus untuk memberi penjelasan kesempatan kerja, menawarkan kepada pihak-pihak yang dianggap memerlukan tenaga lulusan, dan kerja sama antara program studi/jurusan dan pihak pengguna lulusan (BAN-PT, 2008).

Untuk analisis gaji pertama lulusan sebagian besar $(84 \%)$ masih $<1$ juta, hal ini terjadi karena rata-rata lulusan masih bekerja di Bidan Praktik Mandiri sehingga gaji belum dapat disesuaikan dengan upah minimum. Pada tahun pertama lulusan masih mencari pengalaman dalam dunia kerja dan meningkatkan keterampilan yang didapatkan selama proses pendidikan sehingga masih dianggap sebagai karyawan magang.

Kualitas pendidikan diukur melalui indikator proses pembelajaran, kurikulum program studi. Sumber daya manusia, kemahasiswaan, prasarana dan sarana, suasana akademik, keuangan, penelitian dan publikasi, pengabdian kepada masyarakat, dan tata kelola. Berdasarkan hasil analisis gambaran kualitas pendidikan dapat dilihat bahwa indikator yang mendapatkan skor penilaian paling tinggi adalah proses pembelajaran. Menurut Rooijakkers (1991:114) Proses pembelajaran merupakan suatu kegiatan 
belajar mengajar menyangkut kegiatan tenaga pendidik, kegiatan peserta didik, pola dan proses interaksi tenaga pendidik dan peserta didik dan sumber belajar dalam suatu lingkungan belajar dalam kerangka keterlaksanaan program pendidikan.

Suatu sistem pendidikan dikatakan berkualitas jika proses pembelajarannya berlangsung secara menarik dan menantang sehingga peserta didik dapat belajar sebanyak mungkin melalui proses belajar yang berkelanjutan. Proses pendidikan yang berkualitas akan membuahkan hasil pendidikan yang berkualitas pula dan dengan demikian akan semakin meningkatkan kualitas kehidupan bangsa. Dalam dunia pendidikan, terdapat alur yang searah dan sebanding antara input pendidikan, proses pembelajaran dan hasil belajar (output).

Proses pembelajaran yang berkualitas merupakan proses pembelajaran yang member perubahan antara input menuju output (hasil) yang lebih baik dari sebelumnya. Karenanya pembenahan yang menyeluruh dan sistematis perlu dilakukan terhadap input, proses, termasuk didalamnya system evaluasi pendidikan, sehingga dapat menjamin terciptanya kualitas hasil yang tinggi dan merata. (Radno Harsanto, 2007:9).

Pelaksanaan proses pembelajaran di STIKes Respati Tasikmalaya digunakan berbagai pendekatan, strategi, dan teknik yang menantang. Hal ini dimaksudkan agar mahasiswa dapat berpikir kritis, bereksplorasi, berkreasi, dan bereksperimen dengan memanfaatkan berbagai sumber ajar. Pendekatan metode pembelajaran secara bertahap diarahkan berpusat kepada mahasiswa (student centered learning), dengan metode pembelajaran yang dapat mendorong mahasiswa untuk belajar mandiri dan berkelompok.

Indikator kualitas pendidikan yang memiliki skor terendah berdasarkan hasil analisis deskripsi adalah prasarana dan sarana. Pendidikan berkualitas memerlukan tersedianya sarana dan prasarana yang memadai. Pertama dimulai dari ruang kuliah sebagai tempat belajar. Ruang kuliah yang ideal memiliki sound managing dan tata ruang yang baik serta dilengkapi dengan pengatur udara dan sarana visual yang memadai. Tata ruang yang baik sangat menunjang pada optimalnya proses belajar mengajar. Sound managing yang baik meliputi tersedianya sound system yang clear dan efek pemantulan yang baik. Adanya pendingin ruangan memberi kenyamanan baik bagi mahasiswa maupun staf pengajar. Sarana visual yang modern dan up to date mempermudah proses transfer ilmu kepada mahasiswa. Di masa sekarang ini Stikes Respati harus terus meningkatkan sarana pendidikannya khususnya ruang kuliah bukan lagi berorientasi pada standar lokal tetapi standar global.

Kedua, laboratorium praktikum harus dilengkapi dengan peralatan-peralatan yang memadai dan sesuai perkembangan teknologi. Keperawatan sangat erat kaitannya dengan dunia kedokteran sehingga sarana dan prasarana laboratorium praktikum juga harus mengikutinya. Laboratorium pendidikan harus mengacu pada perkembangan teknologi keperawatan dan kedokteran yang berkembang pesat seiring dengan masuknya berbagai teknologi keperawatan dan kedokteran maju disertai dengan peralatan-peralatan canggih ke Indonesia. Saat ini bidang keilmuan keperawatan serta kedokteran tidak lepas dari perkembangan IPTEK. Perkembangan IPTEK ini harusnya bisa dimanfaatkan untuk meningkatkan mutu pendidikan di Stikes Respati pada khususnya.

Ketiga, media pengajaran harus sudah memanfaatkan kemajuan teknologi yang ada. Staf pengajar harus sudah memanfaatkan teknologi komputer dan multimedia. Misalnya, berbagai proses dalam tubuh akan lebih jelas bila diterangkan melalui animasi serta videovideo yang sekarang banyak beredar dalam bentuk CD ROM atau lainnya. Selain itu 
teknologi multimedia dan digital memungkinkan kita menyimpan lebih banyak data dan informasi mengenai perkembangan ilmu pengetahuan terbaru.

Berdasarkan analisis kuadran kepuasan mahasiswa Stikes Respati diperoleh hasil bahwa indicator biaya termasuk kedalam kuadran I dimana biaya dianggap penting namun manajemen belum melaksanakannya sesuai keinginan lulusan sehingga mengecewakan/tidak puas. Menurut Wijaya (2012:119) bahwa "biaya pendidikan merupakan harga dasar atau harga minimum jasa pendidikan yang dikenakan pada produk jasa". biaya merupakan salah satu variable penting karena biaya pendidikan akan menjadi pertimbangan calon mahasiswa untuk memilih perguruan tinggi. Misalnya, suatu perguruan tinggi menetapkan biaya pendidikan yang lebih tinggi dengan mutu yang sama dengan perguruan tinggi lain yang menetapkan biaya yang lebih rendah. Maka dalam hal ini, mahasiswa tentunya akan lebih memilih perguruan tinggi lain yang biaya pendidikannya lebih rendah, namun memiliki mutu pendidikan yang sama. Pada saat mahasiswa membayar biaya pendidikan pada perguruan tinggi pilihannya, maka muncullah sebuah harapan untuk mendapatkan layanan yang sesuai dengan biaya yang telah dikeluarkannya untuk mendapat jasa pendidikan. Dalam hal ini, biaya seringkali dibandingkan dengan mutu layanan pendidikan.

Kualitas layanan berada di kuadran II, dimana indicator tersebut dianggap sangat penting dan memuaskan. Berbagai peneliti telah memberikan temuan mengenai perhatian mahasiswa terhadap kualitas dan penggunaan siswa untuk mengukur kualitas layanan yang disediakan. Mahasiswa harus dinilai sebagai produk dalam suatu institusi (Emery et al, 2001). Penelitian telah menegaskan bahwa kualitas pelayanan merupakan faktor pendukung kepuasan (Cronin dan Taylor, 1992; Shemwell et al, 1998). Kualitas pelayanan dianggap penting oleh berbagai peneliti untuk digunakan dalam sektor pendidikan. Athiyaman

menemukan bahwa ada hubungan yang kuat antara kualitas pelayanan dan kepuasan pelanggan dan semua pertemuan layanan harus dikelola dalam rangka meningkatkan kepuasan konsumen. Ahmed et al. (2010) berpendapat bahwa bahwa ada hubungan positif dan signifikan antara kualitas layanan yang disediakan dan kepuasan pelanggan.

Kandampully (2000) menyatakan bahwa kualitas layanan memiliki peran yang sangat penting bagi kesuksesan bisnis jasa. Dalam bisnis jasa, interaksi konsumen dengan penyedia jasa sangat tinggi, mengingat pada sebagian besar bisnis jasa, pelanggan dituntut keterlibatan dan partisipasinya dalam proses produksi dan konsumsi. Dengan demikian, pelanggan memiliki kesempatan untuk menilai secara kritis kualitas jasa yang disediakan. Pelanggan akan menilai kualitas pelayanan dengan membandingkan antara pelayanan yang diperoleh dengan pelayanan yang diharapkan. Karena itu, kualitas jasa memainkan peran penting dalam memberi nilai tambah terhadap pengalaman jasa secara keseluruhan (Tampubolon et al, 2007).

Temuan di atas memperkuat juga pendapat yang menyatakan bahwa kualitas pelayanan dalam bidang pendidikan akan meningkatkan kepuasan mahasiswa menurut Dimyati (2002) yang menunjukkan hasil penelitiannya bahwa 1) penerapan kualitas pendidikan di Fakultas Ekonomi Universitas Jember memiliki kesenjangan antara harapan mahasiswa dengan persepsi manajemen mengenai kualitas jasa pelayanan, 2) terdapat kesenjangan antara harapan mahasiswa dengan persepsi manajemen mengenai kualitas jasa, khususnya untuk dimensi bukti fisik (tangibles), daya tanggap (responsiveness), dan empati (empathy), 3) terdapat kesenjangan antara harapan penguna lulusan dengan persepsi manajemen mengenai kualitas jasa, untuk 
kelima dimensi jasa (bukti fisik, kehandalan, daya tanggap, jaminan, dan empati.

Penilaian kualitas jasa juga dilakukan oleh Pariseau dan McDaniel (1997) pada sekolah bisnis. Penelitian ini dilakukan pada dua universitas di daerah North-East Region USA. Studi ini membandingkan antara harapan dan persepsi mahasiswa terhadap kualitas pelayanan yang diberikan oleh sekolah bisnis, yang meliputi pelayanan dosen, materi yang diberikan dan pelayanan non akademik. Dalam penelitian ini digunakan lima variabel seperti yang dikemukakan oleh Parasuraman yaitu variabel tangibles, reliability, empathy, responsiveness dan assurance, temuan penelitian ini menunjukkan bahwa mahasiswa menilai bahwa sekolah bisnis harus memiliki tingkat assurance/jaminan yang tinggi kemudian baru diikuti oleh variabel responsiveness, hal ini juga telah sesuai dengan persepsi manajemen sekolah bisnis.

Hasil penelitian Wei dan Ramalu (2011:9) dalam jurnal Students Satisfaction Towards The University: Does Service Quality Matters? menunjukan bahwa secara keseluruhan dimensi mutu layanan berhubungan dengan kepuasan mahasiswa. Penelitian lain yang dilakukan oleh Sureshchandar et al. (2002) menemukan adanya hubungan yang sangat erat antara kualitas pelayanan dengan tingkat kepuasan pelanggan, semakin baik kualitas pelayanan maka besar kemungkinan konsumen akan semakin puas.

Berdasarkah hasil penelitian dan juga pendapat dari beberapa penelitian terdahulu menggambarkan pentingnya kualitas jasa dalam kepuasan mahasiswa. Sedangkan indicator lain seperti kualitas produk dan factor emosional kurang dianggap penting dalam meningkatkan kepuasan meskipun factor-faktor tersebut tetap dipertimbangkan namun tingkat kepentingan mahasiswa terhadap indicator tersebut lebih rendah dibandingkan biaya dan kualitas layanan. Hal ini sesuai dengan yang dikemukakan oleh Helgesen dan Nesset (2007) bahwa Manajemen universitas harus fokus pada layanan kualitas, informasi dan fasilitas untuk meningkatkan kepuasan mahasiswa, dan kualitas layanan adalah paling penting dari semua.

Untuk variabel kepuasan lulusan, terlihat bahwa indikator harga merupakan indikator yang paling dominan dengan besar standar loading factor sebesar 0,92. Selanjutnya indikator kualitas pelayanan $(0,83)$ dan biaya $(0,64)$.

Berdasarkan nilai standardized loading factor dan measurement error serta rumus untuk menghitung Construct Reliability. Terlihat dari tabel diatas menunjukkan bahwa nilai Construct Reliability tiap variabel laten melebihi batas ambangnya yaitu 0,70. Hal ini mengindikasikan bahwa tingkat reliabilitas pada tiap konstruk adalah cukup tinggi, sehingga dapat dikatakan bahwa indikatorindikator pada tiap konstruk cukup konsisten untuk mengukur konstruknya, yaitu variabel kualitas pendidikan dan kepuasan lulusan.

Berdasarkan hasil pengujian hipotesis menunjukkan bahwa terdapat hubungan yang signifikan antara kualitas pendidikan dengan kepuasan mahasiswa. Artinya bahwa semakin baik kualitas pendidikan yang diberikan oleh Stikes maka akan meningkatkan kepuasan mahasiswa. Kualitas pendidikan meliputi proses pembelajaran, kurikulum program studi, sumber daya manusia, kemahasiswaan, prasarana dan sarana, suasana akademik, keuangan, penelitian dan publikasi, pengabdian pada masyarakat serta tata kelola.

Veloutsou et al. (2004) menemukan bahwa mahasiswa merupakan kriteria utama untuk pemilihan mutu pendidikan dan pelayanan yang diberikan di universitas. Mahasiswa merupakan salah satu stakeholder yang paling penting dalam dunia pendidikan. Untuk memenuhi kepuasan mahasiswa merupakan salah satu 
tujuan utama di bidang pendidikan. Kepuasan mahasiswa adalah sumber keunggulan kompetitif dan sumber word of mouth pemasaran untuk lembaga pendidikan. Kepuasan mahasiswa di bidang pendidikan mungkin disebabkan penyediaan kualitas pelayanan di institusi. Untuk melihat apa yang memenuhi kepuasan mahasiswa, kualitas pelayanan lembaga harus diukur.

Wijaya (2012:75) yang mengemukakan bahwa "Kepuasan pelanggan jasa pendidikan adalah salah satu faktor penentu keberhasilan kompetisi pendidikan." Menurut Jurkowitsch, et al (2006:11) "Student satisfaction is defined as the student's fulfilment response." Artinya kepuasan mahasiswa didefinisikan sebagai respon pemenuhan kebutuhan mahasiswa. Sementara itu, Alma (2003:65)

\section{F. Simpulan}

Hasil

pengujian hipotesis menunjukkan bahwa terdapat pengaruh positif antara kualitas pendidikan dengan kepuasan mahasiswa. Artinya bahwa semakin baik kualitas pendidikan yang diberikan oleh STIKes maka akan meningkatkan kepuasan mahasiswa. Kualitas pendidikan meliputi proses pembelajaran, kurikulum program studi, sumber daya manusia, kemahasiswaan, prasarana dan sarana, suasana akademik, keuangan, penelitian dan publikasi, pengabdian pada masyarakat serta tata kelola. Untuk dapat meningkatkan kepuasan lulusan, maka setiap perguruan tinggi harus meningkatkan kualitas pendidikannya.

\section{G. Referensi}

Ahmed, I., Nawaz, M. M., Usman, A., Shaukat, M. Z., Ahmad, N. (2010). Impact of Service Quality on Customer's Satisfaction: Empirical Evidence from Telecom Sector of Pakistan. Interdisciplinary Journal of Contemporary Research in Business, 1 (12): 98-113. mengemukakan bahwa "Agar bisa maju sebuah perguruan tinggi harus mampu memberikan kepuasan maksimal kepada publiknya." Dalam hal ini rektor/ketua sebagai pimpinan perguruan tinggi memiliki tanggung jawab yang besar terhadap perguruan tinggi yang dipimpinnya. Rektor /ketua harus mampu memberikan layanan yang terbaik kepada para mahasiswa sehingga tercipta rasa kepuasan dalam diri para mahasiswa. Senada dengan hal ini, Alma (2003:65) juga mengemukakan bahwa "Sebagai lembaga penghasil jasa, perguruan tinggi, harus memberikan pelayanan yang bermutu, dengan pimpinan yang berkualifikasi baik." Bermutu tidaknya layanan yang diberikan oleh sebuah perguruan tinggi tergantung dari pengelolaan lembaganya.

Akreditasi Program Studi Sarjana. (2008). Jakarta: Departemen Pendidikan Nasional BAN- PT.

Al Rasyid, Harun, (Penyunting : Teguh Kismantoroadji, dkk). (1994). DasarDasar Statistika Terapan, Program Pascasarjana, Unpad: Bandung; 131-4. Arikunto. (1993). Prosedur penelitian suatu pendekatan paktek. Edisi revisi VI. Jakarta: Rineka Cipta.

Aprilia N. (2011). Upaya peningkatan kualitas lulusan [tesis]. Surakarta: Universitas Muhammadiyah.

Athiyaman, A. (1997). Linking Student Satisfaction and Service Quality Perceptions: The Case of University Education. European Journal Marketing. 31 (7): 528-540.

Buchari Alma. (2003). Pemasaran Stratejik Jasa Pendidikan . Bandung: CV.Alfabeta.

Cronin, J. J. Jr., dan Taylor, S. A. (1992). Measuring Service Quality: a Reexamination and Extension. Journal Marketing, 56 (3): 55-68.

David Wijaya. (2012). Pemasaran Jasa Pendidikan "Mengapa Sekolah 
Memerlukan Marketing”. Jakarta : Salemba Empat

Dimyati M. (2002). Analisis Kesenjangan Antara Harapan Dengan Persepsi Atas Kualitas Jasa Pendididkan Tinggi: Kasus di FE Universitas Jember Surabaya. Jurnal Riset Ekonomi dan Manajemen, 1 (1).

Elu B. (2005). Manajemen penanganan komplain konsumen di industri jasa. $\mathbf{J}$ Ilmu Administrasi Organisasi Bisnis Birokasi. 13(3): p. 54-7.

Emery, C. Kramer, T. dan Tian, R. (2001). Customer vs. Product: Adopting an Effective Approach to Business Students. Quality Assurance Education, 9 (2): 110-115.

Hamidin D. (2008). Model Customer Relationship Management (CRM) di Institusi Pendidikan. Seminar Nasional Aplikasi Teknologi Informasi 2008 (SNATI 2008); A-314. Yogyakarta: ISSN 1907-5022. Diperoleh dari: http://www.journal.uii.ac.id/index.php /Snati/article/viewFile/559/483.

[Diakses 21/6/11].

Helgesen, O., dan Nesset, E. (2007). What Accounts for Students' Loyalty? Some Field Study Evidence. International Journal of Educational Management, 21 (2): 126-143.

Jurkowitsch, S et al. (2006). "Student Satisfaction Model for Austrian Higher Education Providers Considering Aspects Of Marketing Communications". Special Edition on Consumer Satisfaction -Global Perspective. Volume 2, Issue 3, 9-22.

Kandampully, J. (2000). The Impact of Demand Fluctuation on the Quality of Service: A tourism Industry Example. Managing Service Quality, 10 (1): 1018.

Narimawati U. (2010). Metodologi penelitian: Dasar penyusun penelitian ekonomi. Jakarta: Genesis.

Panuju R.(2001). Metode Penelitian: Untuk Penulisan Skripsi dan
Tesis.Yogyakarta: Pustaka Pelajar; hlm. 32.

Pariseau, Susan E. dan McDaniel, J. R. (1997). Assesing Service Quality in Schools of Business. International Journal of Quality \& Reliability Management. 14 (3): 204-218.

Pramudiardja. (2012). Indonesia akan mengalami surplus bidan pada 2015. Jakarta. Diperoleh dari: http://health.detik.com/read/2012/02/0 2/132912/1832424/763/indonesiaakan-mengalami-surplus-bidan-pada2015. [Diakses 21/2/2014].

Radno Harsanto, (2007), PEngelolaan Kelas yang Dinamis, Yogyakarta : Kanisius

Rooijakkers, (1991), Mengajar Dengan Sukses, Jakarta: PT. Grasindo

Shemwell, D. J., Yavas, U., dan Bilgin, Z. (1998). Customer Service Provider Relationship: an Empirical Test of A Model of Service Quality, Satisfaction and Relationship Oriented Outcomes. International Journal Service Industry Management, 9 (2): 155-168.

Singgih ML, Rahmayanti. (2008). Faktorfaktor yang memengaruhi kualitas pendidikan pada perguruan tinggi. Prosiding Seminar Nasional Teknoin; 22 November 2008; Kampus ITS Sukolilo Surabaya: Yogyakarta. ISBN: 978-979-3980-15-7; p. 133141.

Sureshchandar, G. S., Chandrasekharan Rajendran, dan R. N. Anantharaman. (2002). The Relationship Between Service Quality and Customer Satisfaction: A Factor Specific Approach. Journal of Services Marketing, 16 (4): 363-379.

Tampubolon, Maria, Perdani Sukmaningrum, dan Serli Wijaya. (2007). Analisa Kepuasan Senior Market Terhadap Kualitas Layanan di Hotel Bintang 4 dan Bintang 5 di Surabaya. Jurnal Manajemen dan Kewirausahaan, 9 (2): 135-143.

Veloutsou, C., Lewis, J. W., Paton, R. A. (2004). University Selection: 
Information Requirements and Importance. International Journal of Educational Management, 18 (3): 160-171.
Wei, Chuah Chin, and Subramaniam Sri Ramalu. (2011). Student Satisfaction toward the University: Does Service Quality Matters?. International Journal of Education. Vol 3, No 2. 